\title{
PROTIOKLEPNI BOJ V SLOVENSKI VOJSKI
}

\section{ANTI-ARMOUR COMBAT IN THE SLOVENIAN ARMED FORCES}

Povzetek Od 90. let prejšnjega stoletja je v opremljanju z oklepno tehniko v oboroženih silah zaznati spremembe. Obseg tankovskih zmogljivosti se je zmanjšal, hkrati pa se povečujejo zmogljivosti tako imenovanega lahkega oklepa in oklepne zaščite $\mathrm{v}$ enotah bojne podpore in enotah zagotovitve bojnega delovanja. Dejansko se je delež oklepa na bojišču povečal. V doktrinarnem smislu Nato ne namenja veliko pozornosti protioklepnemu boju, v Vojaški doktrini SV (2006) pa protioklepnega boja sploh ne najdemo. V članku je opredeljen protioklepni boj v doktrinarnem smislu in analizirane so protioklepne zmogljivosti sodobnih vojsk. Na podlagi tega je predstavljenih nekaj ugotovitev in priporočil o stanju protioklepnega boja v SV.

Ključne Protioklepni boj, protioklepni oborožitveni sistemi, Slovenska vojska, koeficient besede bojne učinkovitosti.

Abstract Since the 1990's, several changes have occurred in armoured formations. The scope of tank capabilities has been reduced, while at the same time the presence of light armour and armour in combat support and combat service support units has increased. The percentage of armour in the battlefield has thus increased. Nevertheless, doctrine-wise anti-armour combat is not a high priority for NATO and it is not even mentioned in the Slovenian Armed Forces doctrine (2006). The article deals with anti-armour combat from a doctrine perspective, and provides an analysis of anti-armour capabilities of modern armed forces. Building on this, it puts forward some conclusions and recommendations regarding anti-armour combat in the Slovenian Armed Forces.

Key words Anti-armour combat, anti-armour weapon systems, Slovenian Armed Forces, combat effectiveness coefficient. 
Uvod Protioklepni boj je v zadnjih 25 letih deležen malo pozornosti tako v Natu kot Slovenski vojski (SV). SV je skozi procese posodobitve pridobila tehnološko izvrstna protioklepna oborožitvena sistema RGW-90 in Spike (Žabkar, 2007, str. 222 in 247), hkrati pa pojma protioklepnega oziroma protitankovskega bojevanja v Vojaški doktrini SV ne najdemo (Furlan, 2006).

Danes prevladuje smer razvijanja univerzalnih oziroma večnamenskih sistemov. Oklepni in protioklepni oborožitveni sistemi naj bi bili sposobni tako boja z oklepnimi kot neoklepnimi cilji podnevi in ponoči ter v vseh vremenskih razmerah, toda kot je že leta 1974 ugotavljal generalmajor Stanković, je absolutna univerzalnost tukaj nemogoča. Hkrati se je struktura oklepnih enot vojsk zelo spremenila in v njih danes prevladuje tako imenovani lahki oklep.

V članku so obravnavani doktrina in načela sodobnega protioklepnega boja. Najprej so na kratko obravnavani trendi ter doktrina in taktika oklepnih enot, ki odločujoče vplivajo na protioklepni boj. Nato so predstavljeni značilnosti, doktrina in sistemi protioklepnega boja. Opredeljene so glavne značilnosti terena v Sloveniji, ki so za oklepni in protioklepni boj ključnega pomena ter pomenijo okvir za določanje velikosti oklepne grožnje, s katero bi se SV lahko soočila. Nazadnje pogleda na protioklepni boj v razmerah delovanja v Sloveniji.Z metodo korelacije matematičnega modeliranja in predvidevanja na podlagi logičnih sklepov (Stankovič, 1974, str. 263) članek primerja razpoložljive protioklepne zmogljivosti na ravni brigade nekaterih sodobnih oboroženih sil in SV, da bi dobili vpogled v protvioklepne zmogljivosti SV.

\section{PRISOTNOST OKLEPA NA SODOBNEM BOJIŠČU IN NJEGOVA UPORABA}

\section{a. Trendi v oklepni tehniki}

Trendi po koncu hladne vojne so kazali na zmanjšano vlogo tanka kot oborožitvenega sistema. Skoraj v vseh državah so zelo zmanjšali ne le obseg oboroženih sil kot celoto, temveč predvsem skupno količino tankov v oboroženih silah. Hkrati je opazno povečevanje stopnje mobilnosti pehote, ki se kaže tudi v razmerju med številom vojakov na oklepne transporterje ${ }^{1}$ vseh tipov. To razmerje je bilo v Franciji leta 199450 : 1, leta 2015 pa se je zmanjšalo na 30 : 1. Podobno je tudi v drugih oboroženih silah² (graf 1, vir: Military Balance 1994 do 2015). Relativni delež oklepa v oboroženih silah se je torej povečal. Hkrati se je spremenilo razmerje med oklepnimi transporterji in bojnimi vozili pehote na eni in tanki na drugi strani (graf 2) v očitno korist prvih. Razmah so doživela kolesna oklepna vozila v vseh mogočih konfiguracijah, in sicer $4 \times 4,6 \times 6$ in $8 \times 8$. Pri oklepnih vozilih je opazen trend opremljanja z vozili, ki zaščitijo pred improviziranimi eksplozivnimi sredstvi. Tanki

\footnotetext{
Pri tem smo upoštevali skupno število bojnih vozil pehote (AIFV) in oklepnih transporterjev (APC), čeprav so to po namenu različni sistemi. Zanima nas namreč le stopnja mobilnosti pehote.

2 Ne povsod tako izrazito, toda dovolj, da je mogoče ugotoviti trend.
} 
Graf 1:

Število vojakov na AIFV + APC
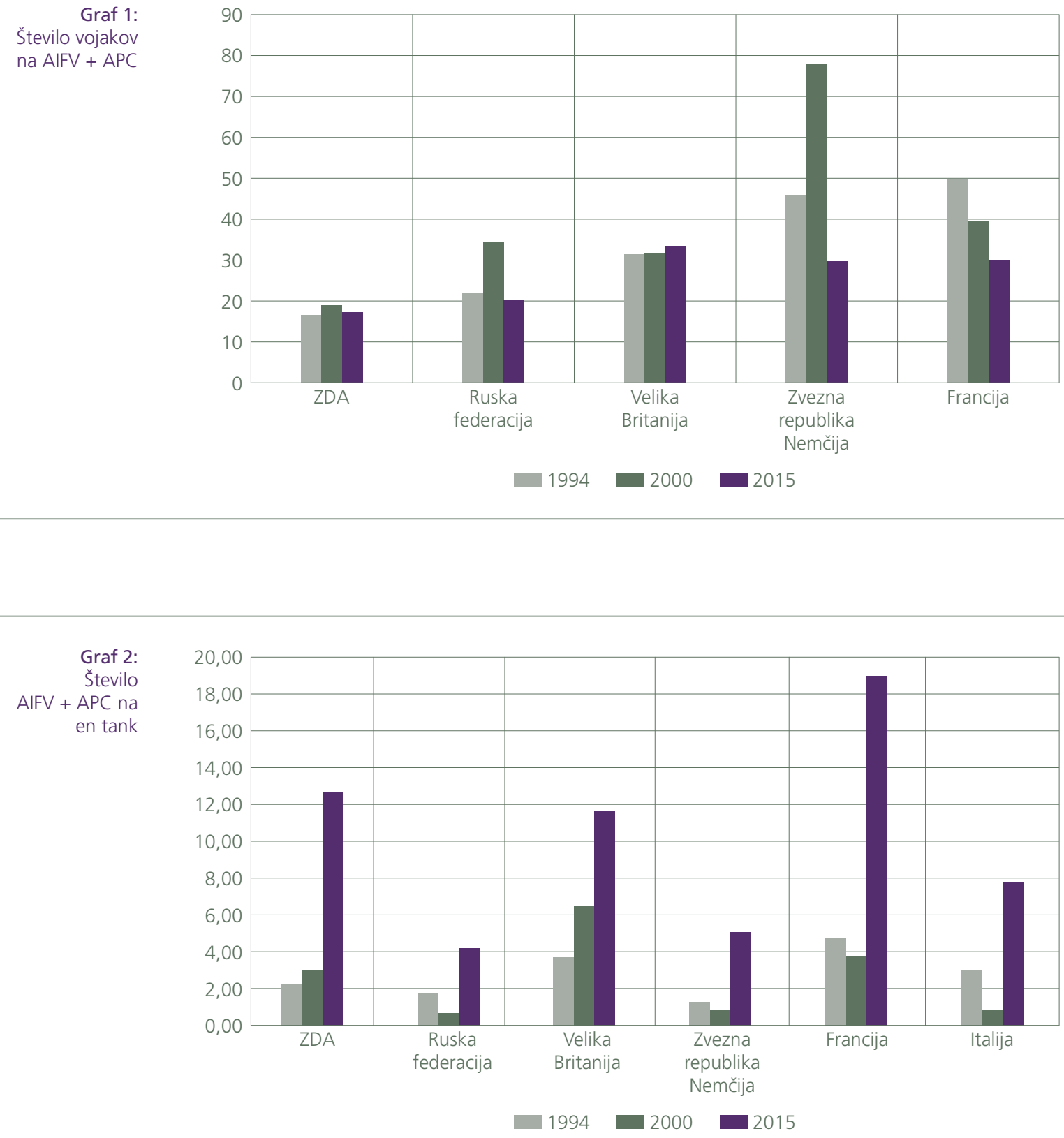

sicer niso izginili z bojišča. Pokazali so se kot uporabni tudi v protiuporniških oziroma protivstajniških operacijah in na naseljenih območjih (Gott, 2006, str. 111-115). Stari tanki se predelujejo v tako imenovane pehotne tanke, hkrati pa se razvijajo novi (Kočevar, 2002, str. 298-301). Študija RAND izpostavlja tri glavne trende v razvoju oklepnih enot, in sicer enote delujejo na geografsko vse večjih območjih, združeno bojevanje rodov poteka že na bataljonski ravni in proliferacija protioklepnega 
orožja zahteva aktivne zaščitne sisteme, preoblikovanje karoserije, $360^{\circ}$ zaščito in elektronske protiukrepe (RAND, 2015, str. 5). Nato je v zadnjem času izrazil potrebo po več oklepnih in mehaniziranih enotah, torej več tankih.

Danes ima ameriška oklepna brigada (HBCT) v svoji sestavi približno 123 tankov M1A2 in približno 127 bojnih vozil pehote Bradley M2/M3. Brigada ameriške vojske Stryker (SBCT) ima več kot 300 vozil Stryker (8 x 8) v različnih izvedenkah. Britanska oklepna brigada ima približno 58 tankov Challenger 2, 90 bojnih vozil pehote Warrior, 300 oklepnih vozil Spartan (specialistično gosenično vozilo) in 90 oklepnih vozil Mastiff $(6 \times 6)$. Pehotne brigade britanske vojske sestavljajo težki bataljoni s 50 vozili Mastiff (oklepniki 6 x 6) in lahki bataljoni s 50 vozili Foxhound (oklepniki 4 x 4). Ruska motorizirana brigada ima približno 31 tankov T-72/80/90, 120 bojnih vozil pehote BMP3/4 in številna druga oklepna specialistična vozila. Temu je treba dodati še izrazite težnje, da se tudi vozila bojne podpore in zagotovitve delovanja opremijo z ustrezno stopnjo oklepne zaščite. Zaščita skoraj vseh oklepnih vozil v osnovi dosega stopnjo 2 , z dodatki pa zaščito do stopnje $4^{3}$. Gosenična bojna vozila in tanki omogočajo še višjo stopnjo zaščite. To je pomembno, saj pomeni, da se pehota s formacijsko oborožitvijo do $12,7 \mathrm{~mm} \mathrm{z}$ njimi ne more učinkovito spopadati.

\section{b. Uporaba in bojni razpored oklepnih enot}

Obstajajo tri splošna načela delovanja oklepno-mehaniziranih enot. Prvo je načelo potrebe po združevanju oklepnih enot, da bi se dosegel ustrezen udar. Drugo načelo je prilagoditev uporabe oklepnih enot lastnostim zemljišča. Tretje načelo zahteva, da se oklep uporablja kot del bojne razporeditve drugih rodov in da deluje skupaj z njimi (Babić, 1981, str. 60-62). Poleg tega so se teorije, po katerih bi se »hitri tanki« ločili od »počasne pehote«, pokazale za zmotne, in je treba druge rodove narediti enako mobilne, kot so tanki. Večina vojsk ima omejene finančne zmožnosti, zato njihovo osnovno bojno moč predstavlja motorizirana pehota. Povezovanje počasne pehote s hitrimi tanki je tako neizogibno (Babić, 1981, str. 62). Babičevo delo je bilo napisano na začetku 80. let, menim pa, da te njegove ugotovitve danes ne držijo nič manj kot v preteklosti. Oklepno-mehanizirane enote niso danes sposobne nič bolj samostojnega delovanja kot pred 30 leti, vojske v svetu pa ves čas iščejo, kako bi pehoto naredile mobilnejšo in bolj zaščiteno, da bi lahko sledila tankom.

Natov pristop k izvedbi kopenskih operacij je manevrski (angl. Maneuverist Approach). Njegovo bistvo je, da je pomembneje uničiti sovražnikovo kohezijo in voljo do boja kot njegova materialna sredstva. Gre za posredni pristop, po katerem je napadanje sovražnikove moralne komponente bojne moči pomembnejše od napadanja njegove fizične moči (AJP, 2009, str. 2-2). Tudi v zavezništvu so težke sile (angl. heavy forces) nosilec boja, toda to niso več tankovske divizije (bataljonske sestave) iz časa hladne vojne, temveč večrodovske enote brigadne ravni, katerih glavna značilnost je zmožnost združenega bojevanja - tako imenovane Joint

3 Glede na Stanag 4569. Dodatni oklep sicer precej poveča težo vozila in tako zmanjša njegovo mobilnost. 
Maneuver Force (ATP, 2009, str. 2-27). Tako danes ne gre pričakovati samostojnih prodorov oklepnih enot brez podpore drugih rodov (pehote, artilerije in letalstva), temveč bojne skupine mešane sestave, v katerih imajo tanki sicer še vedno pomembno vlogo, niso pa prevladujoči. Podobno velja tudi za oborožene sile Ruske federacije, v katerih je na brigadni ravni prav tako uveljavljeno združeno bojevanje rodov.

Oklepne enote so bolj kot kadar koli prej vezane na zmogljivosti preostalih rodov in služb in predvsem na njihovo sposobnost, da sledijo tempu bojevanja, ki ga določajo oklepne enote. Samostojni prodori oklepnih enot so lahko v omejenem obsegu tudi zelo učinkoviti, toda niso in ne morejo biti pravilo.

\section{PROTIOKLEPNI BOJ}

\section{a. Doktrina protioklepnega boja}

V Vojaški doktrini SV (2006) pojma protioklepni ali protitankovski boj ni, V Natovi doktrini kopenske taktike ATP-3.2.1 pa je protioklepni boj obravnavan le znotraj obrambnih aktivnosti. V teh okvirih glavno grožnjo pomeni sovražnikov oklep, zato je protioklepni boj prva poveljnikova prioriteta v obrambi. Sredstvo za uspeh v obrambi je zgodnje uničenje nasprotnikovih tankov. Pri tem je nujno, da so protioklepni sistemi koncentrirani na verjetnih smereh prodora oklepa, da je sovražnik opažen dovolj zgodaj in da so vzpostavljene učinkovite ovire, ki ovirajo premike in kanalizirajo sovražnika. Eden poglavitnih ciljev v protioklepnem boju je tudi čimprejšnja ločitev pehote od tankov. Če nasprotniku uspe prodor prednje črte obrambe, mora protioklepna oborožitev po globini obrambe ta prodor ustaviti, sile v prednji črti pa nadaljujejo boj s prihajajočim oklepom. V Natovi doktrini je poudarjeno, da so jurišni helikopterji najodzivnejši sistem za boj s tankovskimi enotami (ATP, 2009, str. 6-20). V zavezniški doktrini tudi piše, da so neoklepne sile sposobne obrambe le iz vnaprej pripravljenih položajev, ki izkoriščajo naravne in umetne ovire in omogočajo maksimalno izrabo dometa protioklepnih sistemov (ATP, 2009, str. 6-20). Pri tem imajo pomembno vlogo inženirske enote, ki pripravljajo ovire, vključno z minskimi polji, in izdelujejo obrambne položaje za težje orožje (ATP, 2009, str. 6-43).

V ameriški protioklepni doktrini sta poudarjeni množičnost in globina. Skladna je z Natovo doktrino (FM, 2002, str. 1-1). V doktrini nekdanje Jugoslovanske ljudske armade je protioklepni boj opredeljen kot boj, ki se izvaja z neposrednim bojem proti oklepnim silam in sredstvom ter s posrednim delovanjem na infrastrukturo in druge objekte, pomembne za uporabo oklepnih enot (Vidojević, 1980, str. 137).

\section{b. Načela protioklepnega boja}

Načel protioklepnega boja je veliko in so odvisna tudi od doktrine vodenja oboroženega boja (Vidojevič, 1980, str. 153, in Stanković, 1974, str. 180). Glede na zavezniško doktrino in drugo literaturo izpostavljamo naslednja načela. 
- Presenečenje: predstavlja težnjo, da se sovražnikovo oklepno sredstvo prehiti z ognjenim delovanjem.

- Učinkovitost in ekonomičnost: lastne sile so opremljene $\mathrm{z}$ ustreznimi protioklepnimi zmogljivostmi, sposobnimi uničevanja oklepne tehnike, ki bo v oborožitvi potencialnih sovražnikov čez pet do deset let.

- Masovnost: zagotavlja se $\mathrm{z}$ udeležbo vseh rodov $\mathrm{v}$ protioklepnem boju in $\mathrm{z}$ načrtovanjem ter izvajanjem vseh mogočih ukrepov, ki bi oteževali oskrbovanje oklepnih enot.

- Vzajemna podpora: pomeni, da se morajo protioklepne enote in sredstva medsebojno podpirati glede na svoje zmogljivosti in omejitve.

- Neprekinjenost: protioklepni boj ne izvajajo le manevrske enote, temveč tudi enote, ki pokrivajo prostor.

- Uporaba po globini: v napadu so smeri premika in ognjeni položaji izbrani tako, da podpirajo enote, ki napadajo. V obrambi so protioklepne enote na sprednjem krajišču obrambe in se nato premikajo po globini nazaj.

- Združeno bojevanje rodov: protioklepne enote so integrirane z drugimi rodovi, s čimer si povečajo možnosti preživetja in svojo učinkovitost. Pehota zagotavlja varovanje s svojim bojnim razporedom. Protioklepne enote se osredotočajo na uničevanje lahkega oklepa in izkrcane pehote na velikih razdaljah, s čimer omogočijo tankistom, da se koncentrirajo na nasprotnikove tanke. Inženirci oblikujejo bojišče z zagotavljanjem premičnosti, oviranja in preživetja. Ognji sistemov, ki posredno delujejo, uničujejo ali nevtralizirajo sovražnika, upočasnijo sovražnika, razbijajo sovražnikove formacije, onemogočajo sovražnikovo artilerijo in protioklepna orožja ter prikrivajo svoje položaje in premike.

- Bočno delovanje in »Standoff«: če je le mogoče, protioklepni sistemi delujejo v bok ali hrbet oklepu. Protioklepni vodeni izstrelki izrabljajo razliko med svojim dometom in maksimalnim učinkovitim dometom sodobnih tankov.

Tudi v protioklepnem boju se je treba zavedati, da je človek odločujoči dejavnik v boju nasploh. Protioklepni sistemi ne bodo uspešni, če jih ne bo upravljal visoko motiviran, usposobljen in odločen posameznik, pripravljen na boj tudi v najbolj neugodnih razmerah (Vidijević, 1980, str. 160).

\section{c. Sile in sredstva za protioklepni boj}

Sile in sredstva za protioklepni boj delimo na osnovne sile in sredstva, protioklepno oviranje ter sile in sredstva splošnega namena, ki sodelujejo v protioklepnem boju (Vidojević, 1980, str. 138-153). ${ }^{4}$

Osnovne sile in sredstva za protioklepni boj: vlečni protioklepni topovi so danes skoraj izginili iz oborožitve zahodnih vojsk, še vedno pa jih najdemo v ruskih oboroženih silah (2A45M) in ponekod drugje v svetu. Ruski protioklepni top $125 \mathrm{~mm}$ 2A45 je vgrajen tudi v samohodni protitankovski top 2S25, ki ima prav tako možnost

\footnotetext{
So še drugi načini delitve, na primer po tipu, funkciji ali dosegu, vendar potrebam tega članka najbolj odgovarja opisana delitev.
} 
izstreljevanja protioklepnih raket z dometom 4000 metrov. V protioklepni vlogi se lahko uporabijo tudi nekatera zahodna vozila, opremljena s topovi, kot so na primer italijanski Centauro B1 (105 mm) in švedski CV90 120 (120 mm) (Petrović, 2002, str. 79). Sem bi lahko šteli tudi M1128 MGS (105 mm) iz sestave brigad Stryker. ${ }^{5}$

Sodobni protioklepni raketni sistemi (PORS) so učinkoviti med 100 in 4000 metri, imajo možnost samodejnega navajanja na cilj in napadajo občutljivejše dele oklepa. Nekatere izvedenke PORS imajo tudi precej daljši domet, na primer do 8000 metrov. Izstreljujejo se lahko iz helikopterjev in nekaterih sodobnih tankov (Jane's, 2008). Največja omejitev večine sodobnih PORS je hitrost leta rakete, ki je približno $150 \mathrm{~m} / \mathrm{s}$ in je nizka zaradi sistema vodenja na cilj, ki ne dovoljuje višjih hitrosti. V uporabi in razvoju je tudi nekaj PORS, ki to omejitev presegajo, na primer ameriška raketa Hellfire. Ta zaradi samovodenja (laserski, IR, termalni) na cilj lahko dosega bistveno večjo hitrost leta in tako krajšo izpostavljenost strelca ${ }^{6}$ (Petrović, 2002, str. 86).

Sodobni tanki so opremljeni s topovi $120 \mathrm{~mm}$ ali $125 \mathrm{~mm}$ in ohranjajo osrednje mesto v protioklepnem boju. Pomembno je vedeti, da je učinkoviti domet tankovskega topa odvisen od vrste streliva, ki ga uporablja. Navadno so učinkoviti dometi s standardnim protitankovskim strelivom med 2000 in 2500 metrov, z uporabo standardnega visoko eksplozivnega streliva (proti pehoti) pa do 4000 metrov. Sodobni tanki so opremljeni z opozorilniki laserske in radarske osvetljenosti ter drugimi sistemi aktivne in pasivne zaščite. Bistvena prednost tanka v primerjavi s PORS je, da PORS za razdaljo štiri kilometre potrebuje približno 26 sekund $^{7}$, izstrelek tankovskega topa za to razdaljo pa potrebuje le tri sekunde. Ob tem je hitrost streljanja tankovskega topa osem granat na minuto. Prednost PORS je v množičnejši uporabi in ceni.

Za protioklepni boj na majhnih razdaljah (do 500 metrov) se uporabljajo netrzajni topovi(NtT), ročni protioklepni metalci(RPOO), protioklepni trombloni, bombometi, težki mitraljezi, protioklepne mine in priročna protioklepna sredstva. NtT so izgubili svojo protioklepno vlogo. Večinoma so jih nadomestili RPOO in PORS kratkega dosega (Žabkar, 2007, str. 216). Uporaba RPOO je precej razširjena, ker so sodobne različice teh sredstev večnamenske in se lahko uporabljajo tako za boj z oklepom kot tudi proti pehoti in utrjenim točkam ter iz zaprtih prostorov. Njihov učinkoviti domet je med 20 in 500 metri. Pri tem imamo dve različici teh orožij, in sicer orožja za enkratno uporabo (RPOO-1) in orožja za večkratno uporabo (RPOO-2), ki navadno zahtevajo posadko. Protioklepni trombloni so predvsem v psihološkem smislu pomenili veliko prednost. Vojak, opremljen s protioklepnim tromblonom, se je namreč v sili lahko spoprijel z oklepom, vendar se skoraj ne uporabljajo več. Deloma so jih nadomestili RPOO in avtomatski bombometi, ki so ob uporabi ustreznega streliva uporabni tudi za boj proti lahko oklepljenim ciljem (Žabkar, 2007, str. 162 in

\footnotetext{
Ta vozila nikakor niso namenjena boju s tanki, so pa lahko zelo učinkovita v boju z vsem drugim oklepom na bojišču. Učinkovit protioklepni domet topa $2 A 45$ je 2000 metrov, B1 pa je učinkovit le do 800 metrov.

${ }^{6}$ Gre za večkratnike nadzvočne hitrosti-LOSAT, ADKEM in ADATS. Nobeden izmed njih ni v operativni uporabi.

Govorimo o PORS, ki ne deluje prvenstveno po načelu samovodenja.
} 
166). Protioklepne mine se uporabljajo za izdelavo minskih polj in miniranje smeri dostopov do lastnih položajev. Sodobna oklepna tehnika je že projektirana tako, da mine ne uničujejo moštva $\mathrm{v}$ tehniki, temveč $\mathrm{v}$ prvi vrsti onesposobijo vozilo, kar pa učinkovitosti min ne zmanjšuje. Med priročnimi sredstvi najdemo svežnje ročnih bomb, ročne protioklepne bombe, steklenice z vžigalno mešanico in druga improvizirana eksplozivna sredstva, ki spadajo v skrajne oblike protioklepnega boja. Uporaba tovrstnih sredstev je razširjena v uporniških in vstajniških formacijah, ki jim primanjkuje drugega ustreznega orožja za protioklepni boj.

Protioklepno oviranje: glavne naloge protioklepnega oviranja so okrepitev sistema protioklepnega ognja, upočasnjevanje sovražnika, kanaliziranje oklepnih enot, ustavljanje prodora oklepnih enot in prizadejanje izgub v oklepnih sredstvih sovražnika (Vidojević, 1980, str. 145). Protioklepno oviranje je sestavljeno iz minskoeksplozivnih ovir, rušenja, izdelave protioklepnih fortifikacij (eskarpe, protieskarpe, protioklepni rovi, prenosni elementi iz betona in železa, gozdni poseki) ter vodnih ovir (naravnih in umetnih). Protioklepnega oviranja se je treba lotiti že v miru, tako da se pravočasno načrtuje in pripravi rušenje umetnih objektov, okrepijo naravne in umetne vodne ovire, načrtujejo gozdni poseki itn.

Protioklepni boj na velikih razdaljah: za sile in sredstva, ki delujejo na velikih razdaljah, je protioklepni boj le ena izmed nalog, se pa z njimi slabi sovražnikova oklepna moč, še preden vstopi v boj. Te sile in sredstva delujejo na večje skupine sovražnika, sestavljajo pa jih letalstvo, raketna artilerija, cevna artilerija in oboroženi helikopterji. Helikopterji imajo zelo pomembno vlogo v protioklepnem boju. Njihove prednosti so hitrost, sposobnost manevriranja, domet, let na majhnih višinah in sposobnost maskiranja. Sodobne oborožene sile imajo v svoji sestavi specializirane protioklepne helikopterske enote. Tudi raketna artilerija z uporabo specializiranega protioklepnega kasetnega streliva ${ }^{8}$ je pomemben dejavnik sodobnega protioklepnega boja.

\section{d. Načrtovanje protioklepnih zmogljivosti}

Za načrtovanje protioklepnih zmogljivosti lahko uporabimo različne metode matematičnega modeliranja protioklepnega boja (Stankovič, 1974, str. 235-279). Danes v zavezništvu in tudi v SV obstajajo računalniški modeli in simulacije, vendar ne matematično modeliranje ne računalniške simulacije ne morejo upoštevati vseh dejavnikov bojne situacije, zemljišča, vremena in predvsem usposobljenosti in motiviranosti upravljavcev oborožitvenih sistemov. Poleg tega že od arabskoizraelske vojne leta 1973 ni prišlo do množične uporabe enakovrednih oklepnih in protioklepnih sil, ki bi se lahko uporabile za ustrezno analiziranje zmogljivosti sodobnih oklepnih in protioklepnih zmogljivosti. Protiuporniške in protivstajniške operacije tipa Afganistan so povzročile veliko specializacijo oklepnih zmogljivosti, osredotočeno na zaščito pred improviziranimi eksplozivnimi sredstvi na eni strani, na drugi strani pa je protioklepni boj potekal večinoma $\mathrm{z}$ vedno novimi improvizacijami

Pri tem je pomembno, da Konvencija o prepovedi uporabe kasetnega streliva ne prepoveduje uporabe specializiranega kasetnega streliva, kot je protioklepno (Konvencija, 2. člen, 2008). 


\begin{tabular}{|c|c|c|c|c|c|c|c|}
\hline $\begin{array}{r}\text { Tabela 1: } \\
\text { Vrednost } \\
\text { koeficienta bojne } \\
\text { učinkovitosti }(\mathrm{K}) \mathrm{v} \\
\text { različnih pogojih } \\
\text { bojevanja, } \\
\text { izražena s številom } \\
\text { uničenih tankov. } \\
\text { Vir: } \\
\text { povzeto po }\end{array}$ & Protioklepno sredstvo & 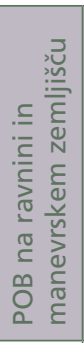 & 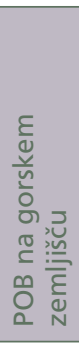 & 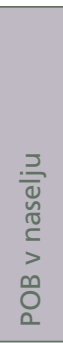 & 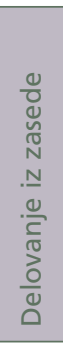 & 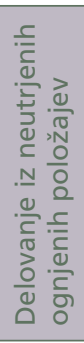 & Opomba \\
\hline \multirow{6}{*}{$\begin{array}{r}\text { povzeto po } \\
\text { Stankovič, } 1974, \\
\text { str. } 273,274 .\end{array}$} & Protioklepni raketni sistemi PORS & 0,5 & 0,3 & 0,2 & 0,5 & 0,3 & $\begin{array}{l}\text { Izgube v lanserjih } \\
\text { se gibajo okrog } \\
30 \text { odstotkov. }\end{array}$ \\
\hline & Jurišno letalo & 0,5 & 0,4 & 0,2 & & & na en nalet \\
\hline & Tank s 120 oz. 125 mm topom & 2 & 1,5 & 2 & 3 & 1 & \\
\hline & $\begin{array}{l}\text { Lovec na tanke s topom 105/125 mm } \\
\text { in lanserjem za PORS }\end{array}$ & 6 & 4 & 3 & 6 & 2 & $\begin{array}{l}\text { pri bojnem kompletu } \\
20-25 \text { granat in } 8 \text { PORS }\end{array}$ \\
\hline & Samohodna top-havbica 122-155 mm & 2 & 1,5 & 1,5 & 3 & 1 & \\
\hline & $\begin{array}{l}\text { Ročna protioklepna orožja } \\
\text { (RPO0-1 in RPOO-2) }\end{array}$ & 0,2 & 0,3 & 0,5 & 0,5 & & $\begin{array}{l}\text { orožja z učinkovitim } \\
\text { dometom do } 500 \text { m }\end{array}$ \\
\hline
\end{tabular}

in orožji kratkega dosega (do 500 metrov). Manjša izjema v tem pogledu so izraelske izkušnje v Libanonu leta 2006, ko se jim je Hezbolah uprl tudi s sodobnejšim PORS in so izraelske žrtve zaradi PORS Hezbolaha predstavljale kar 25 odstotkov vseh žrtev v vojni (Farquhar, 2009, str. 65).

Za potrebe tega članka zato uporabljam koeficiente bojne učinkovitosti ${ }^{9}$ posameznih protioklepnih oborožitvenih sistemov, ki so nastali na podlagi izkušenj druge svetovne vojne in arabsko-izraelske vojne leta 1973 (glej tabelo 1). Dejstvo je, da je v tem času tako oklepna kot protioklepna tehnika napredovala. Domnevam, da se prav zato, ker je napredek očiten na obeh straneh, njihovo medsebojno razmerje ni kritično spremenilo, res pa je, da na določenih oborožitvenih sistemih ni bilo več mogoče izvesti nujnih tehnoloških modifikacij, zato so iz protioklepnega boja izginili.

Številke v tabeli 1 nam pomagajo izračunati protioklepne zmogljivosti določene enote. $\mathrm{V}$ tabeli 2 je prikazano, da je bataljon pehote kopenske vojske ZDA sposoben uničiti 113 oklepnih ciljev. Pri tem smo upoštevali predpostavke, da se protioklepni boj izvaja na manevrskem zemljišču, da se tank giblje s povprečno hitrostjo $25 \mathrm{~km} / \mathrm{h}$ (razen na prednjem kraju predpolja, ko je hitrost $40 \mathrm{~km} / \mathrm{h}$ ), da po strelu s PORS potrebujemo najmanj 30 sekund za ponovno delovanje, da so izgube v protioklepnih sredstvih 30 -odstotne ${ }^{10}$, da tako imenovani Weapons COY sodeluje v protioklepnem boju le na največjih razdaljah, nato pa je uporabljen kot

\footnotetext{
9 Gre za koeficiente bojne učinkovitosti, ko sovražnik deluje po naših silah.

${ }^{10}$ Gre za sisteme, ki so uničeni še pred začetkom bojnega delovanja, med boji ali v bojih iz najrazličnejših (tehničnih) vzrokov ne sodelujejo (TT priročnik JLA, 1967, str. 191).
} 


\begin{tabular}{|c|c|c|c|c|c|c|c|}
\hline \multirow{8}{*}{$\begin{array}{r}\text { Tabela 2: } \\
\text { Protioklepne } \\
\text { zmožnosti } \\
\text { pehotnega } \\
\text { bataljona } \\
\text { kopenske vojske } \\
\text { ZDA }\end{array}$} & \multicolumn{2}{|l|}{ Hitrost tanka } & $\mathrm{v}=25 \mathrm{~km} / \mathrm{h}$ & $\mathrm{v}=25 \mathrm{~km} / \mathrm{h}$ & $\mathrm{v}=25 \mathrm{~km} / \mathrm{h}$ & $\mathrm{v}=40 \mathrm{~km} / \mathrm{h}$ & \\
\hline & \multicolumn{2}{|c|}{ Čas tanka v coni } & $357 \mathrm{~s}$ & $57 \mathrm{~s}$ & $300 \mathrm{~s}$ & $136 s$ & \\
\hline & & & $\begin{array}{l}\text { globina bojne } \\
\text { enote } 2,5 \mathrm{~km}\end{array}$ & $\begin{array}{c}\text { prednje krajišče } \\
\text { obrambe } \\
0-400 \mathrm{~m}\end{array}$ & $\begin{array}{c}\text { predpolje } \\
400-2500 \mathrm{~m}\end{array}$ & $\begin{array}{c}\text { predpolje } \\
2500-4000 \mathrm{~m}\end{array}$ & $\begin{array}{l}\text { Skupaj } \\
\text { ciljev }\end{array}$ \\
\hline & Weapons COY & $\begin{array}{l}8 \times \text { PORS } \\
\text { TOW }\end{array}$ & $\begin{array}{c}8 \times 5^{*} \times \text { TOW } \\
=20 \text { ciljev }\end{array}$ & & & $\begin{array}{l}3 \times 8 \times \text { TOW } \\
=12 \text { ciljev }\end{array}$ & 32 \\
\hline & Scout PLT & $\begin{array}{l}6 \times \text { PORS } \\
\text { Javelin }\end{array}$ & & $\begin{array}{c}1 \times 4^{*} \times \text { Javelin } \\
=2 \text { cilja }\end{array}$ & & $\begin{array}{c}3 \times 6 \times \text { Javelin } \\
=9 \text { ciljev }\end{array}$ & 11 \\
\hline & $2 \times$ INF COY & $\begin{array}{c}12 \times \text { PORS } \\
\text { Javelin }\end{array}$ & & $1 \times 8^{*} \times$ Javelin & $\begin{array}{c}7 \times 12 \times \text { Javelin } \\
=42 \text { ciljev }\end{array}$ & & 46 \\
\hline & $1 \times$ INF COY & $\begin{array}{l}6 \times \text { PORS } \\
\text { Javelin }\end{array}$ & $\begin{array}{c}8 \times 6 \times \text { Javelin } \\
=24 \text { ciljev }\end{array}$ & & & & 24 \\
\hline & \multicolumn{2}{|l|}{ Skupaj ciljev } & 44 & 6 & 42 & 21 & 113 \\
\hline
\end{tabular}

\begin{tabular}{|c|c|c|c|c|c|c|c|}
\hline \multirow{9}{*}{$\begin{array}{r}\text { Tabela 3: } \\
\text { Protioklepne } \\
\text { zmožnosti } \\
\text { bataljonske bojne } \\
\text { skupine SV }\end{array}$} & \multicolumn{2}{|l|}{ Hitrost tanka } & $\mathrm{v}=25 \mathrm{~km} / \mathrm{h}$ & $v=25 \mathrm{~km} / \mathrm{h}$ & $\mathrm{v}=25 \mathrm{~km} / \mathrm{h}$ & $\mathrm{v}=40 \mathrm{~km} / \mathrm{h}$ & \\
\hline & \multicolumn{2}{|c|}{ Čas tanka v coni } & $357 \mathrm{~s}$ & $57 \mathrm{~s}$ & $300 \mathrm{~s}$ & $136 \mathrm{~s}$ & \\
\hline & & & $\begin{array}{l}\text { globina bojne } \\
\text { enote } 2,5 \mathrm{~km}\end{array}$ & $\begin{array}{c}\text { prednje krajišče } \\
\text { obrambe } \\
\text { 0-400 m }\end{array}$ & $\begin{array}{c}\text { predpolje } \\
400-2500 \mathrm{~m}\end{array}$ & $\begin{array}{c}\text { predpolje } \\
2500- \\
4000 \mathrm{~m}\end{array}$ & $\begin{array}{l}\text { Skupaj } \\
\text { ciljev }\end{array}$ \\
\hline & PO vod & $\begin{array}{l}6 \times \text { PORS } \\
\text { Spike }\end{array}$ & $\begin{array}{c}8 \times 4^{*} \times \text { SPIKE } \\
=16 \text { ciljev }\end{array}$ & & & & 25 \\
\hline & $2 \times$ peh. četa & $4 \times$ PORS & & $\begin{array}{c}1 \times 2 * \times \text { PORS } \\
=1 \mathrm{cilj}\end{array}$ & $\begin{array}{l}7 \times 4 \times \text { PORS } \\
=14 \text { ciljev }\end{array}$ & & 15 \\
\hline & & $36 \times$ RPOO- 1 & & $\begin{array}{l}25^{*} \times \text { RPOO- } 1 \\
=5 \text { ciljev }\end{array}$ & & & 5 \\
\hline & $1 \times$ peh. četa & $2 \times$ PORS & $\begin{array}{c}8 \times 2 \times \text { PORS } \\
=8 \text { ciljev }\end{array}$ & & & & 8 \\
\hline & & $18 \mathrm{RPOO}-1$ & & & & & 3 \\
\hline & \multicolumn{2}{|l|}{ Skupaj ciljev } & 27 & 6 & 14 & 9 & 56 \\
\hline
\end{tabular}

protioklepna rezerva in za boj po globini in da je bataljon $\mathrm{v}$ obrambi razporejen $\mathrm{z}$ dvema četama naprej in četo po globini.

$\mathrm{Ob}$ enakih predpostavkah izračun za britanski pehotni bataljon pokaže, da je ta sposoben uničiti 78 ciljev, motostrelski bataljon Ruske federacije pa le 34 ciljev $^{11}$ (tabeli 5 in 6). Enake predpostavke smo uporabljali tudi pozneje pri analizi zmožnosti SV (tabeli 3 in 4).

"Pri tem je pomembno vedeti, da ima ruska brigada na voljo protioklepni bataljon, s katerim lahko oblikuje protioklepne odrede za svoje motostrelske bataljone, ki precej izboljšajo njegove protioklepne zmogljivosti. 


\begin{tabular}{|c|c|c|c|c|c|c|c|}
\hline \multirow{7}{*}{$\begin{array}{r}\text { Tabela 4: } \\
\text { Protioklepne } \\
\text { zmožnosti } \\
\text { pehotnega polka } \\
\text { SV }\end{array}$} & \multicolumn{2}{|l|}{ Hitrost tanka } & $\mathrm{v}=25 \mathrm{~km} / \mathrm{h}$ & $\mathrm{v}=25 \mathrm{~km} / \mathrm{h}$ & $\mathrm{v}=25 \mathrm{~km} / \mathrm{h}$ & $\mathrm{v}=40 \mathrm{~km} / \mathrm{h}$ & \\
\hline & \multicolumn{2}{|c|}{ Čas tanka v coni } & $357 \mathrm{~s}$ & $57 \mathrm{~s}$ & $300 \mathrm{~s}$ & $136 \mathrm{~s}$ & \\
\hline & & & $\begin{array}{l}\text { globina bojne } \\
\text { enote } 2,5 \mathrm{~km}\end{array}$ & $\begin{array}{c}\text { prednje krajišče } \\
\text { obrambe } \\
\text { 0-400 m }\end{array}$ & $\begin{array}{c}\text { predpolje } \\
400-2500 \mathrm{~m}\end{array}$ & $\begin{array}{c}\text { predpolje } \\
2500- \\
4000 \mathrm{~m}\end{array}$ & $\begin{array}{l}\text { Skupaj } \\
\text { ciljev }\end{array}$ \\
\hline & $2 \times$ peh. četa & $4 \times$ PORS & & $\begin{array}{c}1 \times 2^{*} \times \text { PORS } \\
=1 \mathrm{cilj}\end{array}$ & $\begin{array}{l}7 \times 4 \times \text { PORS } \\
=14 \text { ciljev }\end{array}$ & & 15 \\
\hline & & $36 \times$ RPOO-1 & & $\begin{array}{l}25^{*} \times \text { RPOO- } 1 \\
\quad=5 \text { ciljev }\end{array}$ & & & 5 \\
\hline & $1 \times$ peh. četa & $2 \times$ PORS & $\begin{array}{c}8 \times 2 \times \text { PORS } \\
=8 \text { ciljev }\end{array}$ & & & & 8 \\
\hline & & $18 \times$ RPOO- 1 & $\begin{array}{c}13 * \times \text { RPOO- } 1 \\
=3 \text { cilji }\end{array}$ & & & & 3 \\
\hline & \multicolumn{2}{|l|}{ Skupaj ciljev } & 11 & 6 & 14 & & 31 \\
\hline
\end{tabular}

\begin{tabular}{|c|c|c|c|c|c|c|c|}
\hline \multirow{7}{*}{$\begin{array}{r}\text { Tabela 5: } \\
\text { Protioklepne } \\
\text { zmožnosti } \\
\text { britanskega } \\
\text { pehotnega } \\
\text { bataljona }\end{array}$} & \multicolumn{2}{|c|}{ Hitrost tanka } & $\mathrm{v}=25 \mathrm{~km} / \mathrm{h}$ & $\mathrm{v}=25 \mathrm{~km} / \mathrm{h}$ & $\mathrm{v}=25 \mathrm{~km} / \mathrm{h}$ & $\mathrm{v}=40 \mathrm{~km} / \mathrm{h}$ & \\
\hline & \multicolumn{2}{|c|}{ Čas tanka v coni } & $357 \mathrm{~s}$ & $57 \mathrm{~s}$ & $300 \mathrm{~s}$ & $136 s$ & \\
\hline & & & $\begin{array}{l}\text { globina bojne } \\
\text { enote } 2,5 \mathrm{~km}\end{array}$ & $\begin{array}{c}\text { prednje krajišče } \\
\text { obrambe } \\
0-400 \mathrm{~m}\end{array}$ & $\begin{array}{c}\text { predpolje } \\
400-2500 \mathrm{~m}\end{array}$ & $\begin{array}{l}\text { predpolje } \\
2500- \\
4000 \mathrm{~m}\end{array}$ & $\begin{array}{l}\text { Skupaj } \\
\text { ciljev }\end{array}$ \\
\hline & MSC & $\begin{array}{l}12 \times \text { PORS } \\
\text { Javelin }\end{array}$ & $\begin{array}{c}8 \times 8 \times \text { Javelin } \\
=32 \text { ciljev }\end{array}$ & & $\begin{array}{c}7 \times 12 \times \text { Javelin } \\
=42 \text { ciljev }\end{array}$ & & 74 \\
\hline & $2 \times \mathrm{AIC}$ & $18 \times$ RPOO-1 & & $\begin{array}{l}13 * \text { x RPOO- } 1 \\
=3 \text { cilje }\end{array}$ & & & 3 \\
\hline & $\mathrm{AIC}$ & $8 \times$ RPOO-1 & $\begin{array}{l}6 \times \text { RPOO-1 } \\
\quad=1 \text { cilj }\end{array}$ & & & & 1 \\
\hline & \multicolumn{2}{|c|}{ Skupaj ciljev } & 33 & 3 & 42 & & 78 \\
\hline
\end{tabular}

Kako veliko vlogo v protioklepnem boju ima doktrinarni pristop do protioklepnega boja, se kaže v naslednjem dejstvu. Če namreč predpostavko POB na manevrskem zemljišču zamenjamo s POB iz zasede, so številke bistveno drugačne. Pehotni bataljon ZDA ostane na 113 ciljih, zmožnosti britanskega bataljona se povečajo na 84 ciljev, ruskega bataljona pa na 47 ciljev.

\section{e. Organizacijsko-formacijske dileme organiziranja protioklepnega boja}

Sodobni PORS pomenijo veliko grožnjo tankom, predvsem na razdaljah zunaj njihovega učinkovitega dometa, ki je približno 2500 metrov. Dejstvo je tudi, da na sodobnem manevrskem bojišču prevladuje lahek oklep, s katerim se z orožji do kalibra $12,7 \mathrm{~mm}$ ne moremo učinkovito spopadati. Sodobni pogoji manevrskega vojskovanja zahtevajo globoke prodore enot, ki zbirajo informacije 


\begin{tabular}{|c|c|c|c|c|c|c|c|}
\hline \multirow{9}{*}{$\begin{array}{r}\text { Tabela 6: } \\
\text { Protioklepne } \\
\text { zmožnosti } \\
\text { motostrelskega } \\
\text { bataljona RF }\end{array}$} & \multicolumn{2}{|l|}{ Hitrost tanka } & $\mathrm{v}=25 \mathrm{~km} / \mathrm{h}$ & $\mathrm{v}=25 \mathrm{~km} / \mathrm{h}$ & $\mathrm{v}=25 \mathrm{~km} / \mathrm{h}$ & $\mathrm{v}=40 \mathrm{~km} / \mathrm{h}$ & \\
\hline & \multicolumn{2}{|c|}{ Čas tanka v coni } & $357 \mathrm{~s}$ & $57 \mathrm{~s}$ & $300 \mathrm{~s}$ & $136 s$ & \\
\hline & & & $\begin{array}{l}\text { globina bojne } \\
\text { enote } 2,5 \mathrm{~km}\end{array}$ & $\begin{array}{c}\text { prednje krajišče } \\
\text { obrambe } \\
0-400 \mathrm{~m}\end{array}$ & $\begin{array}{c}\text { predpolje } \\
400-2500 \mathrm{~m}\end{array}$ & $\begin{array}{c}\text { predpolje } \\
2500- \\
4000 \mathrm{~m}\end{array}$ & $\begin{array}{l}\text { Skupaj } \\
\text { ciljev }\end{array}$ \\
\hline & PO vod & $6 \times$ PORS & $\begin{array}{c}8 \times 4^{*} \times \text { PORS } \\
=16 \text { ciljev }\end{array}$ & & & $\begin{array}{c}3 \times 6 \times \text { PORS } \\
=9 \text { ciljev }\end{array}$ & 25 \\
\hline & $2 \times$ peh. četa & $4 \times$ RPOO-2 & & $\begin{array}{c}2 \times 4 \times \text { RPOO- } 2 \\
=2 \text { cilja }\end{array}$ & & & 15 \\
\hline & & $18 \times$ RPOO-1 & & $\begin{array}{c}13 * \times \text { RPOO-1 } \\
=3 \text { cilji }\end{array}$ & & & 5 \\
\hline & $1 \times$ peh. četa & $2 \times$ RPOO-2 & $\begin{aligned} 8 \times 2 & \times \text { RPOO- } 2 \\
= & 3 \text { cilji }\end{aligned}$ & & & & 8 \\
\hline & & $9 \times$ RPOO-1 & $\begin{array}{c}8 \times 2 \times \text { RPOO- } 1 \\
=1 \text { cilj }\end{array}$ & & & & 3 \\
\hline & \multicolumn{2}{|l|}{ Skupaj ciljev } & 27 & 6 & 14 & 9 & 56 \\
\hline
\end{tabular}

za potrebe manevrskega poveljnika. $\mathrm{V}$ teh pogojih je velika verjetnost, da naletijo na sovražnikove oklepne zmogljivosti v vseh mogočih oblikah in morajo biti za boj z njimi ustrezno opremljene. To pomeni opremljenost tako s PORS kot RPOO, avtomatskimi bombometi in težkimi mitraljezi, kar je odvisno od tipa in nalog enote.

Obstaja dilema, kako za protioklepni boj opremiti mehanizirane enote. Ali s PORS opremiti vsako vozilo, da je avtonomno v protioklepnem boju, ali oblikovati namenske protioklepne enote (Stankovič, 1974, str. 201)? Menim, da je danes, ko je na bojišču razmeroma malo tankov, veliko bolj smiselno in racionalno oblikovati namenske protioklepne zmogljivosti, ki jih uporabljamo na najverjetnejših smereh prodora tankov oziroma kot protioklepno rezervo. Z drugimi oklepnimi grožnjami na sodobnem bojišč se mehanizirana pehota lahko spopada s topom svojih vozil $(20+\mathrm{mm})$. To kaže tudi pregled protioklepnih zmogljivosti ZDA, Velike Britanije in Ruske federacije.

Obstaja tudi dilema glede opremljenosti pehote z ročnim protioklepnim orožjem (RPOO). Veliko RPOO v enotah najnižje taktične ravni lahko povzroči pasivnost precej vojakov za čas, ko ne poteka intenziven protioklepni boj. RPOO tudi ovira pehotnega vojaka pri gibanju po bojišču. Poleg tega je v primeru, ko gre za RPOO za večkratno uporabo (RPOO-2), poleg strelca $\mathrm{v}$ boju pasiven tudi njegov pomočnik ${ }^{12}$ (Stankovič, 1974, str. 204), toda iz čisto psihološkega vidika morajo tudi enote najnižje taktične ravni zadržati protioklepne zmogljivosti. Če pogledamo rešitve referenčnih oboroženih sil, vidimo, da pehotne enote ZDA v oborožitvi RPOO nimajo več, temveč imajo v vodih oddelke PORS Javelin, Britanci so v oddelkih še zadržali RPOO-1, vojska Ruske federacije pa tako RPOO-1 v oddelkih kot RPOO-2

${ }_{12}$ Tudi v tem primeru gre za boj, ki ni protioklepen. V primeru slednjega je posadka RPOO-2 zelo dejavna. 
na ravni čete. ${ }^{13}$ Uvedba PORS na raven vodov in čet pomeni veliko finančno obremenitev, pomembno pa je tudi vprašanje zahtevnosti usposabljanja operaterjev in s tem trajanja ter stroškov. Po drugi strani je dejstvo, da je RPOO-1 ali RPOO-2 lahko zelo učinkovit pri delovanju iz zased in v boju v naselju (glej tabelo 1) ter je v tem elementu primerljiv s PORS.

Bataljoni pehote ${ }^{14}$ potrebujejo mobilno protioklepno oborožitev daljšega dometa (najmanj 2500 metrov), ki se poleg boja s tanki lahko spopada tudi z orožji za neposredno streljanje večjega kalibra ter z ognjenimi in utrjenimi točkami (Stankovič, 1974, str. 202), torej potrebujejo univerzalno protioklepno orožje. Netrzajni topovi žal nimajo več sposobnosti boja s sodobnimi tanki in so umaknjeni iz uporabe sodobnih vojsk. Nadomestili so jih ustrezni PORS oziroma v nekaterih primerih tako imenovani lovci na tanke, kot so 2S25, Centauro B1, CV90 120 in pogojno MGS.

V mehaniziranih in motoriziranih enotah bi morala biti vsa artilerija samohodna in imeti spodobnost protioklepne borbe (Stankovič, 1974, str. 203). To je danes standard vseh sodobnih vojsk. Protioklepne zmogljivosti je artilerija še izboljšala s sodobnim vodenim in kasetnim strelivom.

Za boj z lahkim oklepom (do vključno standarda K3) ter za boj z oklepom enot bojne podpore in zagotovitve bojnega delovanja so uporabna tudi orožja kalibra $12,7 \mathrm{~mm}$ in več, ter avtomatski bombometi $\mathrm{z}$ ustreznim prebojno-eksplozivnim strelivom. Tako je smiselno namenske protioklepne enote (vode in čete) opremljati tudi s temi oborožitvenimi sistemi na vozilih, saj namenske protioklepne enote pridobijo univerzalnost in racionalnost $\mathrm{v}$ uporabi.

Stanje je nekoliko drugačno v enotah, ki so namenjene pokrivanju prostora. Zanje velja, da so namenjene predvsem delovanju v zaledju in na zasedenem ozemlju. Pri tem je ena temeljnih nalog onemogočiti sovražniku napad (Furlan, 2006, str. 28, 48). To niso sile, ki bi bile namenjene manevrskemu delovanju, zato je zaseda eden izmed glavnih načinov njihovega bojnega delovanja. Pri tem gre za boj na majhnih (do 500 metrov) in izjemoma srednjih razdaljah (do 2000 metrov), za kar so primerna protioklepna orožja kratkega dosega (RPOO), ki v tem načinu delovanj dosegajo koeficiente učinkovitosti blizu ali celo boljše od PORS (tabela 1).

\footnotetext{
${ }^{3}$ V preteklosti se je neučinkovitost PORS na kratkih razdaljah do 500 metrov reševala z uporabo RPOO. PORS so bili zaradi načina izstrelitve in vodenja na cilj do razdalje približno 500 metrov neuporabni. Sodobni PORS so učinkoviti tudi že na zelo kratkih razdaljah (Javelin od 65 metrov naprej), zato se pojavlja vprašanje smiselnosti uporabe RPOO.

${ }^{14}$ Motorizirana, gorska, zračno-jurišna in zračnodesantna po Natovi klasifikaciji.
} 


\section{GEOGRAFSKI DEJAVNIKI IN SMERI PRISTOPA V SLOVENIJI}

Prehodnost Slovenije je zaradi značilnosti reliefa, poseljenosti in pogozdenosti na splošno zelo omejena. Slika 1 (na str. 135) kaže nagib terena v Republiki Sloveniji, kjer vse, kar ni obarvano z modro barvo, predstavlja naklon, večji od 20 stopinj, ki je za oklepno-mehanizirane enote že težko premagljiv. ${ }^{15}$

Slovenija ima 9,7 odstotka površine z nadmorsko višino do 200 metrov, 45,6 odstotka od 200 do 500 metrov, 34 odstotkov od 500 do 1000 metrov in 10,7 odstotka z nadmorsko višino več kot 1000 metrov (vir e-gradivo). 58,4 odstotka površine Slovenije je pogozdene (vir: Zavod za gozdove). Iz tega sledi, da je v Sloveniji manever oklepnih enot omejen, bi pa bilo napačno domnevati, da je nemogoč. To sledi tudi iz zgodovinskega pregleda, ki ga najdemo v knjigi Oklep na Slovenskem (Kočevar, 2008, str. 61-64, 85-89, 111-113, 237-241).

V splošnem sta vzhodni in jugovzhodni del Slovenije bolj prehodna, a tudi tam je manever omejen z gričevjem, ki sicer ne onemogoča premikov oklepa, ga pa upočasni in delno kanalizira. Ta del dovoljuje razvoj večjih oklepno-mehaniziranih formacij tudi do ravni brigade, vendar bi bil njen manever pogosto omejen na raven bataljona in čete. Druge smeri z jugovzhoda občasno omogočajo razvitje enote ravni bataljona, vendar pa bi bil manever pogosto kanaliziran na raven voda. Južne smeri od Bele krajine do obale ne dovoljujejo razvoja oklepno-mehaniziranih enot, večjih od čete. Večinoma bi bile omejene na vodno raven ali preprosto kolono vozil. Z zahodne smeri je prodor oklepno-mehaniziranih enot mogoč le med Novo Gorico in Tržičem. Zahodne smeri ob obali in čez kraško planoto ne omogočajo več kot manever bataljona. Že Postojnska vrata manever kanalizirajo na raven kolone vozil. Z zahoda bi bil mogoč še prodor oklepa v dolino Soče, toda omejen na raven voda. Iz doline Soče proti vzhodu je vsakršen manever nemogoč in je premik omejen na kolono. S skrajnega severozahodnega dela bi bil mogoč prodor oklepa ravni čete po dolini Save. Od Jesenic do Ljubljane bi bil mogoč razvoj enot brigadne ravni. $\mathrm{Na}$ severu so Karavanke velika naravna ovira, ki omejuje vsakršen prodor oklepa na raven kolone vozil, dokler ne prodrejo v Ljubljansko kotlino. Koroška smer s koncem Karavank dovoljuje manever mehanizirane enote ravni čete (na sliki 2, str. 135).

$\mathrm{Ob}$ tem je treba povedati, da so tudi zgoraj opisane smeri zaradi vodovja, pogozdenosti in poseljenosti velikokrat kanalizirane na enoto vsaj eno raven nižje oziroma na raven kolone. Zaradi razmeroma dobro razvejene cestne mreže je mogoče v notranjost Slovenije prodirati v formaciji kolone še na drugih vzporednih smereh, toda te so zaradi vegetacije, reliefa in poseljenosti v resnici omejene na kolone in ne omogočajo skoraj nikakršnega manevra. To velja tudi v nasprotni smeri - torej za potrebe premika manevrskih enot SV.

\footnotetext{
${ }^{15}$ M. Babić navaja, da je zemljišče med 20 in 25 stopinjami naklona že nepremagljivo za oklepna vozila (Babić, 1981, str. 274). Tudi pregled taktično-tehničnih lastnosti sodobnih tankov pove, da so vzponi več kot 60 odstotkov (27 stopinj) in bočni nagibi več kot 30 odstotkov (13,5 stopinje) zanje nepremagljivi.
} 
Iz zgoraj napisanega sledi, da bi glavne smeri prodora oklepno-mehaniziranih enot lahko zapirali že z dobro organiziranim oviranjem in protioklepnim bojem na ravni polka, čete in voda. Zaradi geografskih značilnosti je razen Prekmurja in vzhodne Štajerske do Slovenske Bistrice najprimernejše zasedno delovanje. Hkrati se je zaradi množice vzporednih poti, ki omogočajo premik oklepnih kolon, treba lotiti dobro organiziranega protioklepnega boja prostorskih sil.

\section{SV IN PROTIOKLEPNI BOJ}

Resolucija o splošnem dolgoročnem programu razvoja in opremljanja SV do leta 2025 opredeljuje razvojne ambicije na področju protioklepnih oborožitvenih sistemov. Določa, da bodo zadržane tankovske zmogljivosti okrepljene čete tudi zaradi zmogljivosti protioklepnega boja in da bo SV razvila sodobne prenosne in prevozne protioklepne raketne zmogljivosti (ReDPROSV 2025, 2011, str. 35).

Na podlagi SOPR 2013-2018 in objav v reviji SV lahko ocenimo trenutne protioklepne zmogljivosti SV. SV ima tankovsko četo v okviru logistične brigade. $\mathrm{Na}$ ravni pehotne brigade ima protioklepne čete, opremljene s sistemi Spike. (SOPR, 2013, str. 34). Iz njih se oblikuje protioklepni modul, najverjetneje vod, za bataljonske bojne skupine. Na ravni pehotne čete ima SV oblikovane protioklepne enote v vodu za podporo, opremljene s PORS ${ }^{16}$ (Oblak, 2015, str. 21). RPOO-1 RGW-90 je najverjetneje na ravni oddelka.

Izmed preostalih oborožitvenih sistemov, ki niso namenjeni predvsem protioklepnemu boju, se pa v njem lahko uporabljajo, ima SV na razpolago še težke mitraljeze 12,7 mm FN M2HB QCB in avtomatske bombomete 40 mm Heckler \& Koch GMG, sisteme za posredno ognjeno delovanje, kot so minometi $120 \mathrm{~mm}$ in top havbica $155 \mathrm{~mm}$, ter pogojno tudi letala PC-9M. Inženirske zmogljivosti v inženirskih četah se uporabijo tudi za protioklepno oviranje.

Problematična je izjava vodje usposabljanja operaterjev PORS SV decembra 2015: »Taktika je precej podobna izvidništvu ... Naloge enote so razporejene tako, da širšega zavarovanja ne moremo izvajati, zato potrebujemo dobro izvidniško taktiko ... Enote ne delujejo znotraj večjih formacij, temveč se po terenu premikajo prikrito in z ustrezne točke opazujejo teren neprekinjeno do 72 ur. Ta način delovanja je značilen tudi za specialne in izvidniške enote ..." (Oblak, 2015, str. 20). To je v popolnem nasprotju z doktrino in taktiko protioklepnega boja. Upamo, da je pri tem prišlo do napake ali napačne interpretacije povedanega.

\footnotetext{
${ }^{16}$ Pri tem gre za orožja neznanega tipa. Domnevno so sistemi SPIKE v POČ brigade, s SOPR pa ni predvidenih nabav novih PORS, zato so to lahko samo sistemi 9 K111 Fagot. Za slednje se zastavlja vprašanje njihove operativne uporabnosti.
} 
Tabeli 3 in 4 prikazujeta oceno trenutnih protioklepnih zmogljivosti SV na podlagi javno dostopnih podatkov. ${ }^{17}$ Kot lahko vidimo, ocenjene zmogljivosti SV na ravni polka in tudi BBSk močno zaostajajo za sodobnimi trendi, analiziranimi prej. BBSk je s protioklepnim vodom brigade tako sposobna ustaviti 56 ciljev, polk pa le 31. Če predpostavimo, da SV na ravni čete trenutno nima operativnega PORS, so številke alarmantne - 33 ciljev za BBSk in le osem ciljev za polk.

\section{Sklepi in predlogi za Slovensko vojsko}

Analiza zemljišča je pokazala, da v Slovenijo iz vseh sosednjih pokrajin vodi več med seboj ločenih smeri, ki se prej ali slej zožijo na raven voda oziroma kolone. Za tako zemljišče je najprimernejša oblika bojnega delovanja zaseda. Na posameznih smereh je smiselno voditi protioklepni boj na velikih razdaljah do 4000 metrov. V vzhodni polovici države je treba imeti zmožnost večje koncentracije protioklepnih zmogljivosti.

Sodobni protioklepni boj na ravni brigade temelji na dveh oborožitvenih sistemih: na tankih in protioklepnih raketnih sistemih. Nad to ravnjo imajo sodobne oborožene sile namensko za protioklepni boj oblikovane enote jurišnih helikopterjev z dosegom 4000 metrov in več ter raketno artilerijo, opremljeno s specializiranim protioklepnim strelivom. S temi se v članku nismo ukvarjali, saj ocenjujem, da presegajo zmogljivosti, ki bi jih lahko imela SV. Ob kakršni koli množičnejši tankovski grožnji bi morala SV tovrstne zmogljivosti zagotavljati v okviru zavezništva.

RGW-90 in Spike sta kakovostna oborožitvena sistema, toda protioklepni boj ne more temeljiti na RGW-90, sistemov Spike pa je v oborožitvi enot SV premalo ${ }^{18}$. Tank M84 je še vedno sposoben tudi boja s primerljivimi tanki in bi ga bilo nujno vključiti v sestavo manevrskih brigad SV.

Slovenija je del Nata in se je z njim dogovorila, da bo zagotovila več zmogljivosti kot svoj prispevek k skupni varnosti. Najpomembnejši zmogljivosti v tem dogovoru, ki pomenita vojaško pomemben prispevek v zavezništvo, sta srednji bataljonski bojni skupini (SrBBSk). Menim, da mora SV v SrBBSk vzpostaviti zadovoljive protioklepne zmogljivosti (vod). Naše mnenje se $\mathrm{v}$ tem delu ne ujema $\mathrm{z}$ uradnim stališčem SV in MO, ki ne sprejemata argumentacije, zapisane v 2. e točki. Vsa vozila v manevrskih četah SrBBSk naj bi opremili s PORS (Kralj, 2015, str. 34). Ocenjujem, da je to povsem nepotrebno. Naš predlog je po drugi strani tudi precej laže uresničljiv s sedanjimi sistemi v inventarju SV. Za oblikovanje dveh SrBBSk

\footnotetext{
${ }^{17}$ Gre za oceno zmogljivosti protioklepnega boja (POB) na manevrskem zemljišču. Za POB iz zasede so številke nekoliko višje (70 ciljev za BBSk in 43 za pehotni polk).

18 Ocena temelji na dostopnih podatkih, iz katerih sledi, da so brigadne POČ sestavljene iz prejšnjih protioklepnih vodov bataljonov. SV je domnevno kupila dovolj sistemov Spike samo za popolnitev teh vodov, zato njihovo število komaj lahko zadostuje za popolnitev zdajšnjih brigad POČ. Tako lahko domnevamo, da čete niso popolnjene s PORS, saj SPOR ne predvideva nakupa dodatnih PORS. Alternativa so sicer stari sistemi 9K111 Fagot, ki so bili v oborožitvi SV, a jih na uradni spletni strani SV ne najdemo več. Njihova operativnost je najmanj vprašljiva.
} 
potrebujemo dva protioklepna voda (navadno šest PORS), preostale PORS iz protioklepnih čet brigad pa bi bilo treba razporediti v protioklepne oddelke (navadno dva PORS) motoriziranih oziroma mehaniziranih čet ${ }^{19}$. To sicer pomeni skupaj 24 PORS, kar je malo več, kot domnevamo, da jih ima SV. ${ }^{20}$

RPOO-1 na ravni oddelka zadostuje tako za BBSk kot pehotne polke SV. Prisotnost RPOO-1 na ravni oddelka je izjemno pomembna s psihološkega stališča in kot drugo je RGW-90 večnamenski sistem, sposoben uničevanja neoklepnih ciljev, kar je za pehoto zelo koristno. V formacijo oddelkov ni smiselno dajati več kot eno protioklepno orožje. Dodatni RPOO-1 se iz polkovnih rezerv (dodatni RPOO-1) v enote dodajo, ko pričakujemo močnejšo oklepno grožnjo, tako da se lahko oblikujejo protioklepne skupine na ravni vodov.

Sodobni PORS srednjega dosega do 2500 metrov so dragi sistemi, ki poleg vsega zahtevajo tudi dobro usposobljene operaterje, kar zahteva čas in denar. Po drugi strani je zaradi zemljišča in zemljepisnih značilnosti v Sloveniji najprimernejše zasedno delovanje, zato menim, da PORS na ravni čete ni najboljša rešitev za enote SV v RS. Za potrebe SV v RS bi zadostovali sodobni RPOO-2 na ravni čete. Poleg tega je RPOO-2 primeren za delovanje na razdaljah, na katerih so PORS neučinkoviti oziroma manj učinkoviti zaradi specifičnosti delovanja sistema in vodenja na cilj (približno do 200 metrov). To ne spremeni dejstva, da je treba četam v SrBBSk, namenjenim v operacije zavezništva, zagotoviti PORS. Vozila enot za podporo bi bilo smiselno opremiti s težkimi mitraljezi $12,7 \mathrm{~mm}$ in avtomatskimi bombometi $40 \mathrm{~mm}$ za boj z lahkim oklepom.

Za samoobrambo je nujna protioklepna zmogljivost na ravni polka SV, ki je SV nima, in sicer v obliki protioklepnega voda, kot smo ga že poznali v bataljonih SV pred transformacijo. Ta enota mora biti sposobna izvajati protioklepni boj na razdaljah do 2500 metrov, kar predstavlja učinkovit domet tankovskega topa in topov spremljajočih bojnih vozil pehote. Na ravni brigade oblikovane protioklepne čete bi se ob predpostavki oblikovanja brigadne bojne skupine za delovanje v RS ${ }^{21}$ morale zadržati zaradi specifičnih značilnosti zemljišča, ki od poveljnika brigade zahtevajo visoko mobilno protioklepno rezervo, z deli katere lahko, če je treba, okrepi katero koli smer prihoda oklepnih enot oziroma okoli katere lahko oblikuje večje protioklepne zmogljivosti ob večjih tankovskih koncentracijah sovražnika (brigade). Hkrati je treba protioklepne enote na ravni polka in brigade opremiti z vozili, ki zagotavljajo ustrezno mobilnost in oklepno zaščito. Vozila morajo biti za boj z lahkim oklepom in svojo zaščito opremljena s težkimi mitraljezi 12,7 mm in avtomatskimi bombometi $40 \mathrm{~mm}$. Četa tankov v brigadi bi morala zaokrožati protioklepne zmogljivosti SV.

\footnotetext{
19 Tako bi kompenzirali trenutni domnevni primanjkljaj v sistemih PORS na ravni čete.

${ }^{20}$ Domnevamo, da ima SV približno 20 sistemov PORS Spike, saj so bili s prejšnjim SOPR predvideni le za tri bataljone (za 132gbn niso bili predvideni), $k$ temu pa lahko prištejemo še rezervo, ki jo SV skoraj gotovo ima.

${ }^{21}$ Predpostavka izhaja iz ReSDPRO 2025, za katero pa menim, da je sicer neprimerna.
} 
Artilerijske enote SV so pomemben element protioklepnega boja. Tudi s klasičnim strelivom so lahko učinkovite proti koncentracijam lahkega oklepa. V boju s tanki in bojnimi vozili pehote z uporabo bližinskih vžigalnikov lahko uničuje sovražnikove namerilne naprave, opozorilne sisteme in druge izpostavljene sisteme na zunanji strani oklepa. V protioklepnem boju je zelo pomembna tudi njena sposobnost zadimljevanja bojišča. V okviru zavezniških operacij v protioklepnem boju imajo pomembno vlogo tudi usmerjevalci združenih ognjev (angl. JTAC), ki so usposobljeni tudi za usmerjanje jurišnih helikopterjev na zemeljske cilje in za usmerjanje bližnje letalske podpore.

Inženirske enote SV morajo imeti sposobnost gradnje utrjenih položajev za protioklepne sisteme in vsaj omejene sposobnosti protioklepnega oviranja. V inženirskem smislu priprave terena se ogromno naredi že v miru z ustrezno pripravo linijskih objektov in identifikacijo območij oviranja v naravi.

Trenutno stanje na področju protioklepnega boja v SV je slabo. Protioklepni sistemi v oborožitvi komaj zadostujejo potrebam oblikovanja dveh BBSk, pri čemer preostanek SV ostane brez PORS, predvsem pa se mora protioklepni boj vrniti v Vojaško doktrino. Poveljujoči protioklepnih enot morajo poznati osnovna načela in doktrino Natovega protioklepnega boja, da bi se lahko uspešno vključili v operacije zavezništva s pravilnim načrtovanjem protioklepnega boja na ravni BBSk. SV mora za potrebe delovanja v domovini razviti doktrino protioklepnega boja, ki bo ustrezal prevladujočim terenskim in vremenskim razmeram in protioklepnim sistemom $\mathrm{v}$ oborožitvi enot ter bo skladen z Natovo doktrino.

1. ATP 2-01.3, 2014. Intelligence preparation of the battlefield/battlespace. Headquarters Department of the Army, Washington D.C.

2. Babić, M., 1977. Bliska protivoklopna borba. Vojnoizdavački zavod, Beograd.

3. Babić, M., 1981. Taktika oklopnih jedinica u opštenarodnom odbrambenom ratuudžbenik. Savezni sekretarijat za narodnu odbranu, GŠ JNA.

4. Barabanov, M., 2011. Russia's New Army. Centre for Analysis of Strategies and Technologies, Moscow, Russia.

5. Brijukov, G. F., in drugi, 1970. Borba protiv tenkova. Uprava Artiljerije, Beograd.

6. Brinc in drugi, 2006. Angleško-slovenski vojaški terminološki slovar. PDRIU, http://intra. mors.si/index.php?id=1718 (13. 6. 2015).

7. Chipman, J., 1994. The Military balance 1993-1994. IISS, London, UK.

8. Chipman, J., 2000. The Military balance 1999-2000. IISS, London, UK.

9. Državni zbor RS, 2010. Resolucija o splošnem dolgoročnem programu razvoja in opremljanja Slovenske vojske do leta 2025. Ljubljana: MO RS.

10. Državni zbor RS, 2009. Zakon o ratifikaciji konvencije o kasetnem strelivu (MKKS). Ljubljana.

11. Farquhar, S. C., 2009. Back to basics: A Study of the Second Lebanon War and Operation CAST LEAD. Combat Studies institute Press, US Army CAC, Fort Leavenworth, Kansas.

12. FKSM 71-8, 2010. Armor/Cavalry reference data; Brigade combat teams. US Army Armor Center, Fort Knox, KY.

13. Foss, F. C., 2011. Jane's Armour \& Artilery 2010-2011; thirty-first edition. Sentinel House, Surrey, UK. 
14. FM 3-21.91, 2002. Tactical employment of antiarmor platoons and Companies. Headquarters department of the Army, Washington, D.C.

15. FM 34-130, 1994. Inteligence Preparation of the battlefield. Headquarters department of the Army, Washington D.C.

16. Furlan, B. (in drugi), 2006. Vojaška doktrina. Defensor, Ljubljana.

17. Garb in drugi, 2009. Razlagalni vojaški slovar, http://intra.mors.si/index.php?id=1718 (13. 6. 2015).

18. Geršak, T., 1991. Pehotni bataljon proti oklepu-zgovorne primerjave za našo rabo. Revija Obramba številka 8-9, Ljubljana.

19. Hacket, J., 2015. The Military balance; the annual assessment of global military capabilities and defence economics 2015. IISS, London, UK.

20. Jones, R. D., in Leland, N., 2008. Jane's Infantry Weapons 2008-2009. Biddles Ltd., Kings Lynn, Great Britain.

21. Kočevar, I., 2008. Oklep na Slovenskem. Defensor, Radomlje.

22. Kralj, Ž., 2017. Oblikovanje srednjih bataljonskih bojnih skupin Slovenske vojske. Revija SV, str. 34-35, MO RS, Ljubljana.

23. NATO, 2009. Alied Land Tactics - ATP-3.2.1. NATO Stardandisation Agency.

24. NATO, 2009. Allied Joint Doctrine for Land Operations-AJP-3.2. NATO Stardandisation Agency.

25. NATO, 2013. AAP-06 Edition 2013, NATO glossary of terms and definitions (English and French). NATO Stardandisation Agency.

26. Oblak, N., 2015. V 10. PEHP novi operaterji raketnega sistema. Revija SV, MO RS, Ljubljana.

27. Otmann, S., Defense and Freedom, New Russian Brigade TO\&E, http://defense-andfreedom.blogspot.com/2009/10/new-russian-brigade-to.html (23. 6. 2015).

28. Petrović, D., 2002. Artiljerija sveta. Tricontinental, Beograd.

29. RAND, 2015. Comparing U.S Army Systems with Foreign Counterparts; Identifying Possible Capability Gaps and Insights from Other Armies. RAND Corporation, Santa Monica, California.

30. Vlada RS, 2013. Srednjeročni obrambni program Republike Slovenije 2013-2018. Ljubljana, št. 80300-1/2013/3 z dne 1. 2. 2013.

31. Žabkar, A., 2007. Pehotna oborožitev in oprema - stanje in smeri razvoja. Založba Defensor, Ljubljana.

32. Stanković, M., 1974. Protivoklopna borba. Vojnoizdavački zavod, Beograd.

33. SVS STANAG 4569(1), 2010. Stopnje zaščite uporabnikov logističnih in lahkih oklepnih vozil. Republika Slovenija, MO RS.

34. Vidojević, V., in Dimitrijević, Č., 1980. Upotreba i dejstvo protivoklopnih artiljerijskih jedinica (baterija - divizion) - udžbenik. SSNO, GŠ JNA, Beograd.

35. Slovenska vojska, Oborožitev in oprema, http://www.slovenskavojska.si/oborozitev-inoprema// (16. 10. 2015).

36. Gozdovi Slovenije, http://www.zgs.si/slo/gozdovi_slovenijelo_gozdovih_slovenije/ slovenskigozd_vstevilkah_2012/index.html (10.12. 2015).

37. Mobility Corridors width, http://solutions.arcgis.com/military/land-operations/templates/ maot/workflows/create-mcoo/ (28. 10. 2015).

38. The British Army, Formations, ARMOURED INFANTRY BRIGADE, http://www.armedforces.co.uk/army/listings/l0013.html (23. 6. 2015).

39. The British Army, Formations, THE ROYAL MARINES, http://www.armedforces.co.uk/navy/listings/l0038.html (29. 11. 2015).

40. The British Army, Formations, ARMOURED INFANTRY BATTALION, http://www.armedforces.co.uk/army/listings/l0033.html (23. 6. 2015). 
Slika 1

Figure 1

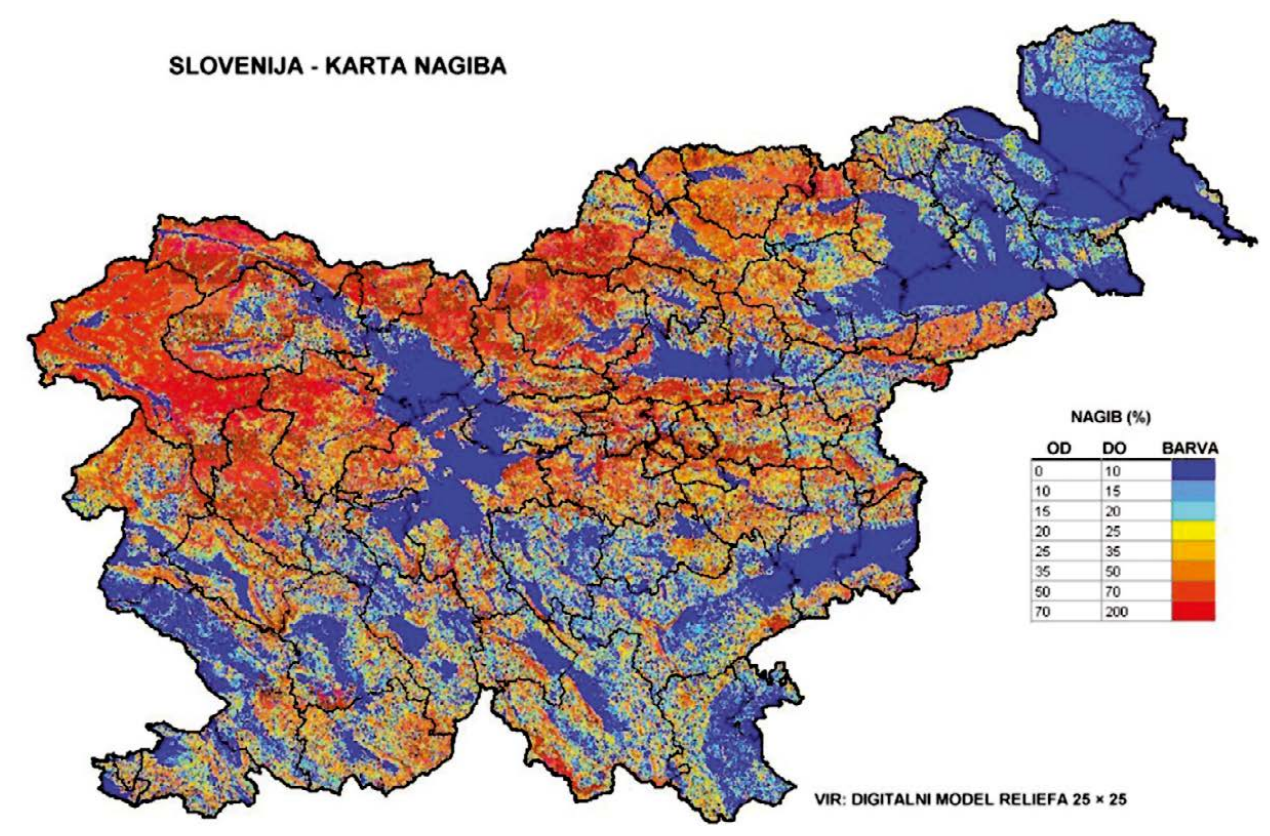

Slika 2

Figure 2

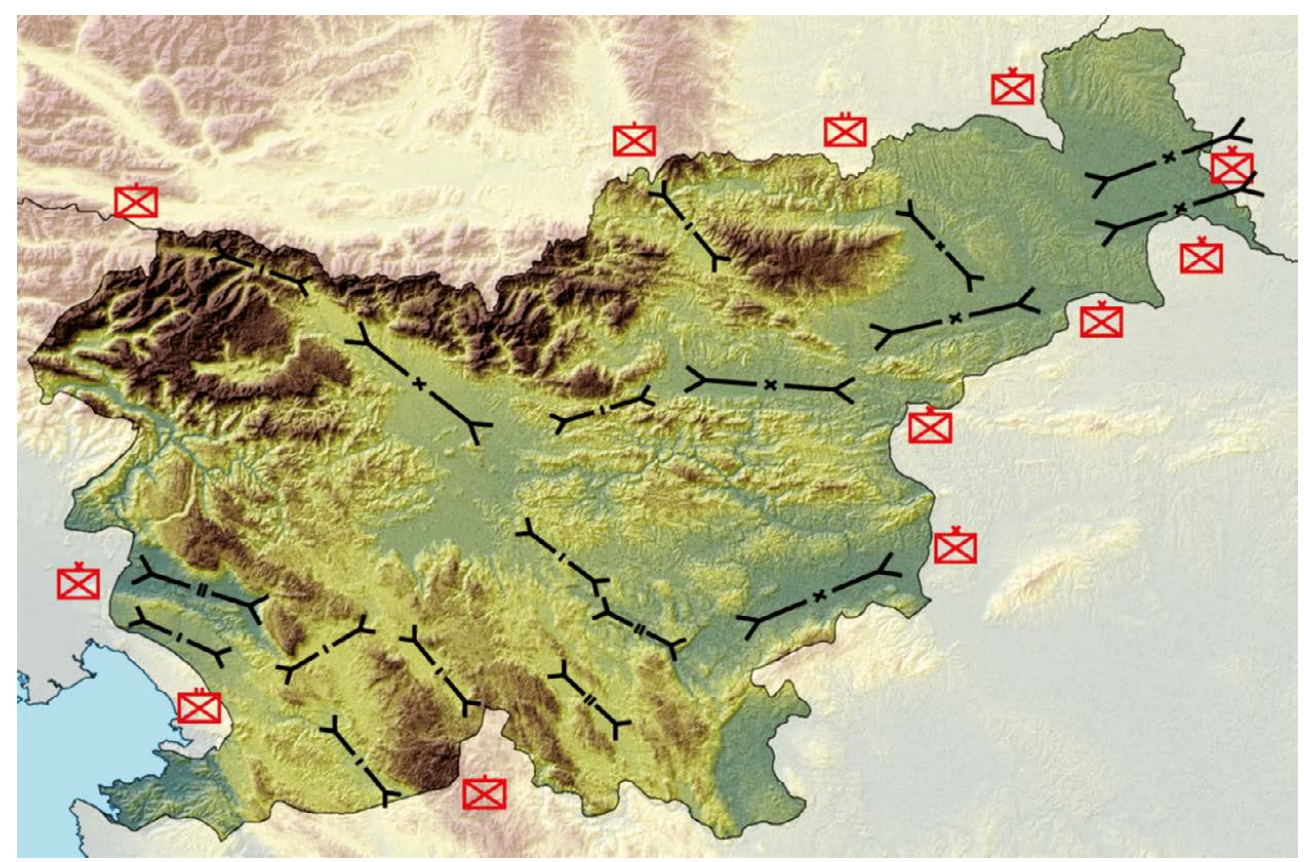

